\title{
Fourth Wave Feminism in Indonesia: Body Shaming Through Social Media Phenomenon
}

\author{
Noviyanti Soleman', Rifki Elindawati² \\ ${ }^{1} K$ hon Kaen University, Thailand \\ 2University of Indonesia, Indonesia \\ 'Email: noviyantisoleman6@gmail.com
}

\begin{abstract}
Recently, Indonesia has been horrified by the phenomenon of body shaming through social media. Even though this has happened previously, but now the victims take serious action to respond the situation, including filed reports on the police based on violations of the ITE Law Article 27 paragraph (3) in conjunction with Article 45 paragraph (3) of Law No 11 of 2008. However, some people still do the body shaming especially through social media by disguising body size, imperfection and appearance. Based on the data, there are 966 cases of body shaming in 2018. Furthermore, this research aims to assess the body shaming through social media phenomenon in Indonesia which has the relations with the fourth wave feminism issues. To answer the research question, the writers use objectification theory and feminist constructivism approach. This study deployed the qualitative research instrument by primary and secondary data. The result shows that body shaming through social media in Indonesia caused by natural and social order that formed people's habit in daily life.
\end{abstract}

Keywords: Body Shaming; Constructivism; Feminism; Social Media.

\section{Introduction}

The feminism issues have been discussed since eighteenth century (first-wave feminism), the issues mostly talk about women's right. Going through long period, the focus of the issues has been progressing followed by the dynamic of society. This also happened in Indonesia, feminism in Indonesia has a long story and contributed to the discourse 
of equality (Arivia \& Subono, 2017) The feminist movement in Indonesia has taken action since the Dutch colonialization's era till during the post-colonialization, meanwhile growing number of women's organization become historical records of feminist movement in Indonesia. They dealt with issues such as equality right and participation (Arivia \& Subono, 2017).

Nonetheless, many feminist scholars believe that the contemporary issues of feminist have entered new phase following the social dynamics, called the fourthwave feminism. Based on Prudence Chamberlain in her books The Feminist Fourth Wave Active Temporality (2017) argued that the issues of fourth wave feminism include the justice for women, particularly to counter sexual harassment and violence against women. To handle feminism issues, Indonesian government and some advocated groups have tried to raise awareness of the citizen towards the issues, such as by developing national law to executing the case related to the issues and campaigns that has been done by some NonGovernmental Organizations.

In using technology, the government had set the regulation by ratified Electronic Information and Transactions Law (UndangUndang ITE, ITE Law) in 2008 and later was revised in 2016, the aims of the regulation are to protect, manage electronic information and transaction. In ITE Law also accomodates the regulation about body shaming, through Article 27 paragraph (3) in conjunction with Article 45 paragraph (2) of Law No 11 of 2008. Both articles conclude that every person intentionally and/ or without rights to distribute and/ or transmit and/or make access to electronic information and/or electronic documents that have insulting contents can be punished for (maximum) 6 months and/ or paying fine (maximum) IDR. $1,000,000,000$ ( \pm USD. 71,000), this also applies to body shaming activity.

Against to the background, eventhough it has been well regulated in the national law and the criminals will get the sanction, body shaming phenomenon still happen in Indonesia, particularly through social media. Based on Detik.com, during 2018 there were 966 case related to body shaming recorded by the police in Indonesia. 374 cases had resolved either using the law procedure or mediation between the victims and the perpetrators 
(Santoso, 2018). Thus becomes the highlighted issues in this research.

\section{Feminism in Indonesia}

The phenomena of fourthwave feminism has also been widely discussed recently. This regards to issues that have not been covered by first-, second-, and third-wave feminism. Fourth-wave feminism tries to focus on enhace human equality through the use of internetbased technologies, empowerment of all marginalized groups in society, inculing women and girls (Chamberlain, 2017).It is a followup conversation that began in 1848 with the aim of fighting for women's rights.

Before the existence of fourthwave feminism, there are three wave of feminism that exists with different focus study. The current wave that called fourth-wave feminism is combined with the era of technology by using the social media as the tool. The fourth wave aiming to advocate women in politics and business. The focuses of the news had been added in fourth wave feminism such as salary in workplace, sexual harassment and assault, sexual entitlement, freedom of individual choice, discrimination, body shaming, online misogyny, intersectionality and many others.
In her article, 'Feminism: $A$ Fourth-Wave?' Ealasaid Munro claims for the fourth feminism that it has been enabled by internet, particularly social media facilitating call-out culture (Munro, 2013). Social media has allowed for the continual challeging of sexism and misogyny, creating environment in which feminism can directly engage with that which it is agains. Not only the numbers of women online increasing, but also multiple feminist campaigns have been launched on the internet (Chamberlain, 2017). Most of the focus issues was related to the technology such as social media.

The use of technology is a good alternative to campaign the women right, considering the social media now became a tool of the people among the world to communicate. Meanwhile more than $50 \%$ population around the world use the internet and around $42 \%$ use social media. There are no limit of time and space in using social media. Bates and Soraya Chemaly did the campaign of $4^{\text {th }}$ wave feminism against misogynist through facebook pages and Bridget Christie also railed against sexiest comments and concerning ethical filing in social media (Cochrane, 2013). 
Body shaming is one of the topic issue that fourth-wave feminism focusing on. The word body shaming is very famous around the world. According to Cambridge dictionary, body shaming is criticism of someone based on the shape, size, or appearance of their body (Gaffney, 2017). Katelyn J. Gaffney on her research mentioned that the side effect of body shaming is resulted eating disorder, anxiety, anger, dissatisfaction of the body and depression. She also mentioned about the phenomena of body shaming around the world such as in America, Britain and Australia (Gaffney, 2017).

The trend of body shape on social media is common along with the huge number use of social media. There are some challenges in social media that might be led to body shaming indirectly such as 'iPhone knees challenge' that can prove the skinny of the legs, collarbone challenge by coin to show the sexy of their collarbone, 'A4 challenge' to prove the tiny of their waist, and many others. Those challenges are indirectly shows the discrimination to them who did not have "specific" size of bodies, because they cannot join and enjoy the challenge in social media.

Heather R. Gallivan on his presentation about Teens, Social Media And Body Image shows the list of data regarding to the social media and body shaming, the study he conducts in Univeritsy of Haifa found out that A 2011 study from the University of Haifa found that the more time girls spent on Facebook, the more they suffered conditions of $\mathrm{AN}, \mathrm{BN}$, poor body image, negative approach to eating and more urges to be on a weight loss diet. One residential eating disorder treatment center found that $30-50 \%$ of their patients are actively using social networking sites to support their eating disorders. (Gallivan, 2014). Dina Borzekowski, professor at Johns Hopkins school of public health also notes that social media may have a stronger impact on children's body image than traditional media. Messages and images are more targeted, if the message comes from a friend it is perceived as more meaningful and credible.

\section{Research Question}

The previous study shows that there is relations between body shaming and social, furthermore this paper would like to assess why does the body shaming through social media happen in Indonesia in regards with fourth-wave feminism? 


\section{Literature Review}

\section{Objectification Theory}

According to Fredrickson and Roberts (1997), objectification theory posits that girls and women are typically acculturated to internalize an observer's perspective as a primary view of their physical selves and will be lead to habitual body monitoring. The impacts of being sexual objectification is poor mental health both direct and indirect (Fredickson \& Roberts, 1997). Melanie S. Hill and Ann R Fischer try to form a framework based on Fredrickson and Roberts idea of objectification theory (Hill \& Fischer, 2008).

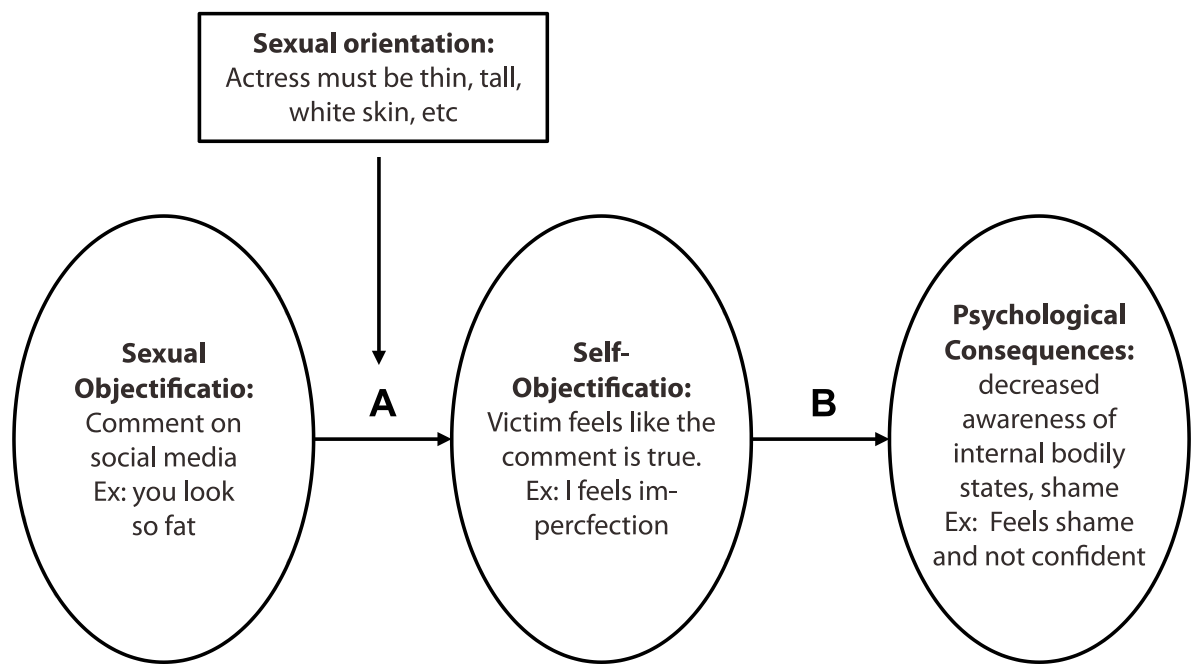

Source: (Hill \& Fischer, 2008) based on Fredickson and Roberts (1997)

The chart explains that in path A there is influence from observer of sexual orientation that can bring the sexual objectification to be selfobjectification. The people who get self-objectification by the observer tend to have self-objectification or they are be able to evaluate their own body based on people's perspective that they think it was a standard. in Path B and C shows that the existence of health disorder range from shame to the depression. Path D shows the direct impact from sexual objectification. So we see the two impacts of sexual objectification may be happens direct and indirect.

\section{Constructivism Approach}

This research will use the constructivism approach, to explore the reason of body shaming 
in social media still happens in Indonesia despite all the advocacy efforts. The basic insight behind the constructivist approach can be understood by unpacking a quick observation made by Archer that argued that the norms or value that infiltrated in particular society is not given, it comes from the interaction of people with their environment. Besides, the causal power also can be modify.

The properties and powers of the human being are neither seen as pregiven, nor as socially appropriated, but rather these are emergent from our relations with our environment. As such they have relative autonomy from biology and society alike, and causal powers to modify both of them' (Archer, 2000).

Archer uses perspective if Merleau-Ponty points out that the 'sensed bodily enveloped' is critical to the development in the sense of self-distinguished from others (Archer, 2000). This self-constituted in practical activity in relation with natural needs. Archer maintains that looking for an 'entity or substance', the self is an emergent property whose realization comes from the necessary relations between embodied practice and the nondiscursive environment (Archer, 2000).
Archer continues her argument with an examination of the emotional inner life all human being that grounds all human development. In the natural order the concern is about the physical well being of the body in the environment and emotional reaction is visceral. In the practice order the concern is for subject or object relations and the concern is for competent performance or achievement. And in the third, the discursive order, the concern is also for subject or object relations but the concern is for self-worth in the light of normative strictures. The dilemma for any individual is, of cours, that these three orders are not, in practice, distintc and there are no guarantees that they are compatible. As a result, the contradiction of firstorder concersn and commentaries givers rise to the second-order emotionality that is concerned with striking a balance between the three orders dan it is the particular balance that each individual strikes that produces the personal identituy of that person.

Second order concerns arise out of the human ability to reflect upon our emotions, to transform them and thus to set up the priorities among emotions that are particular to ourselves. It is through 
our inner conversations, involving discernment, deliberation and dedication in morphogenetic cycle that second-order emotionally is elaborated and personal identity is formed. The achievement of personal identity through second order emotionally is not automatic and there are instabilities, often through second-order emotionality over the life cycle, that prompt new dialogue and change commitments. The emergent subject that Archer outlines is a stratified concerp involving different powers and properties at each emergent level. The four strata comprise the self, the person, the agent and the actor. The agent and the actor are social selves but they are dependent upon the continues sense of self and they are co-dependent with the emergence of personal identity.

The social sel develops at the interface of structure and agency. But in contrast, to person, structure and culture all face emergent power and properties. It is in the interplay of all three components that social change is affected and either one of the three may be the precipitting trigger of change. Archer points out that chave tendency to accelrate most especially under conditions of modernity. Archer's social relatist position accords sui generis causal power to all three components, which are culture, sturcture and agents.

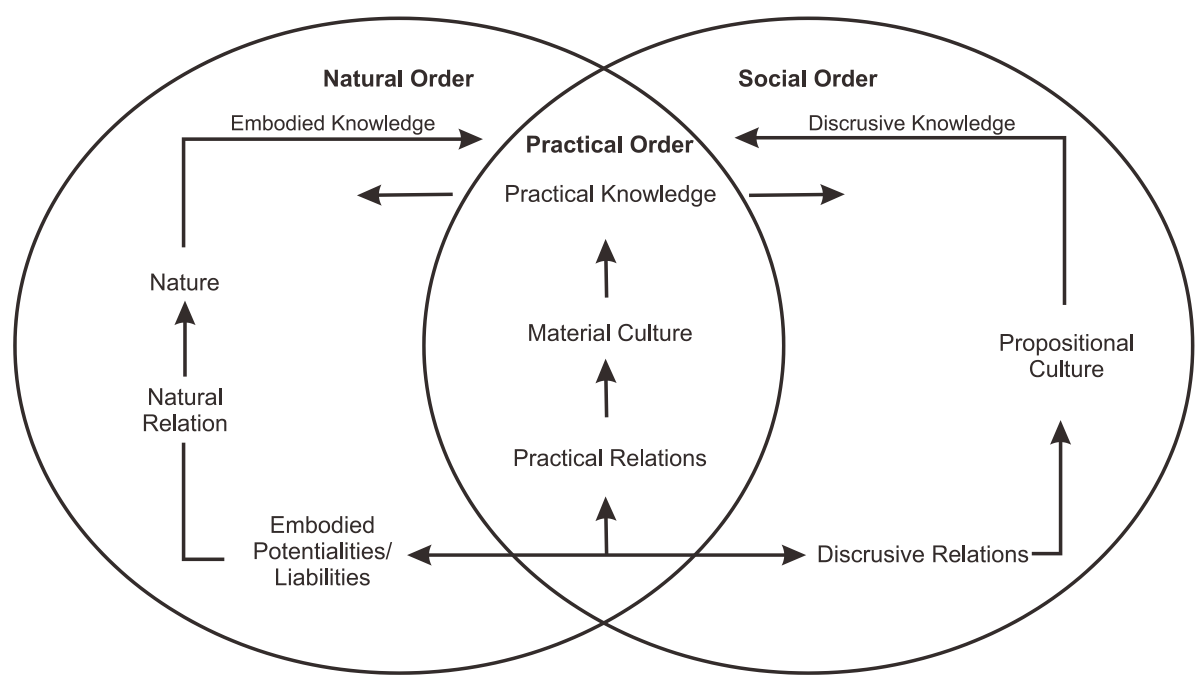

Source: (Clegg, 2006) based on Archer (2000) 


\section{Methodology}

In order to answer the research question, this research is using qualitative research method. A qualitative data is not convert all of the result into a single data as number but leaves the data in a varieties forms (Neuman, 2014). The writers used primary data through observation and secondary data by the books, journal, news and others document related to the body shaming on social media in Indonesia. This research is counted as the phenomenological research.

\section{Result}

\section{Social Media Misuse}

The regulation of ITE Law is clearly stated, the bullies of body shaming will be punished based on Article 27 paragraph (3) and Article 45 paragraph (2). The regulation shows that the Government of Indonesia has taken serious action towards body shaming activities. It is also to prevent the further activities of body shaming and the misuse of media for defamation or insults. This cannot be denied that the number of body shaming on social media is also related to the length of social media usage in Indonesia since social media is providing a platform to a wide range of women, who are able to use the connectivity.

In recent year, Indonesia has greater internet penetration with 88 million people connected online, including 79 million active social media users. Based on the global digital report 2018 that merge the data reports from We Are Social and Hootsuite, Indonesia is one of the top five countries that spend many hours in using internet per day. Indonesia placed in fourth which is approximately $8 \mathrm{~h} 50 \mathrm{~m}$ per day. In $8 \mathrm{~h} 50 \mathrm{~m}$, Indonesian user spend $3 \mathrm{~h} 20 \mathrm{~m}$ for only social media, in this case Indonesia is still in big three after Philippines and Brazil. In January 2017, the annual growth of social media users from Indonesia is $23 \%$. (Kemp, 2018). Indonesia is also ranked high for social media penetration with 111 million Facebook users, it comes as fourth the biggest uses globally and the first in Southeast Asia. The country has 24 million users on Twitter, one of the highest in the world, and 8.9 million are on Instagram (Rakhmat \& Tarahita, 2017).

Along with the high numbers of internet penetration in Indonesia, including social media, this study finds the cases relating to social media also differ with their various motives. In 2009, cases of body 
shaming on social media occurred on the basis of jealousy. At that time a teenage girl named Felly commented on the Facebook status of a man named Ujang to decide his girlfriend Farah. Looking at the comment, the boyfriend felt uncomfortable and jealous and then chose to reply to the comment using the man's account. Farah commented on Felly that she has unproper body shape, not fashionable, to the family of Felly (Gunawan, 2009).

The other case study happened to some public figures in Indonesia. The public figures always have been on the spotligtht, since their works engage with public and broad audiences. Many people make public figures as role models such as fashion, but not a few also give negative comments to the public figures such as commenting on body shape. As it is known to almost all artists have experienced this, but there are some artists who choose not to care about people's comments. The following is a case of body shaming on social media that befell public figures, such as momshaming happens to many public figures. During pregnancy it is very normal if a woman experiences changes in body shape, but many actually comment on changes in body shape. Tasya Kamila,
Putri Titian, and Audi Item, the famous publc figures in Indonesia experience the body shaming, most of the bullies commented that their body getting fatter while pregnant and still fat after delivering the babies.

Dian Nitami's case has just happened recently. She chose to send her report to the police about the body shaming that she experienced on Instagram social media made her not confident. This case was then processed by the authorities, even though the person actually doing it was an educated person. Besides being insulted by one of her body part, Dian is also advised to do plastic surgery to improve his body shape. Aside from Dian Nitami, actress Ussy Sulistiawati chose the legal route for the body shaming experienced by her daughter. Immediately, she brought 20 account names of social media that insulted her daughter's body. Besides, there are still many public figures who experience similar malicious comments about body shape, such as skin color experienced by Nana Mirdad and Ariel Tatum, height experienced by Prilly Latuconsina, Rossa, Brisia Jodie, Aurel Hermansyah, to the case of Rina nose who chose to release 
her hijab and still many other cases of humiliation.

From the illustration case above, it is shown that social media is place to share their activity, such as in the form of pictures and people are able to communicate with other through social media, however, the relationship that exists can also be negative towards other people. Here in the case of giving harsh comment towards certain body part to other people, they might just want to comment to show their dissatisfaction or dissagreement towards certain part of the people's body, because it has an ideal body construction in their thinking.

\section{Lack of Attention of the Issues}

The feminsts groups in Indonesia has been well aware about the feminism issues, some significant action had been taken to handle the issues, such as Women's March in Jakarta earlier that become the annual event of feminists campaign to commemorate the International Women's Day. In 2018, the Women's March highlighted the issue of violation, harassment and harmful of traditional practices against women, the issue of early marriage also became a concern in the march. The march also demands the Government of Indonesia to establish pro-women and promarginal groups public policy (BBC, 2018).

The other campaign like $\mathrm{Fe}$ minist Fest Indonesia has also showed its notable action by holding the festival that explore the use and importance of feminism in Indonesia in $21^{\text {st }}$ century. The Feminist Fest sessions include plenary panels, small group discussions, workshops, and classes with quite a number of themes, including gender based violence, sexual and reproductive health, sexual orientation and gender identity, eco-feminism, and public policy. This festival specifically targets young people who already have an interest in joining the movement and striving to achieve gender equality and fulfill women's rights in Indonesia (FEMFEST, n.d.). Both Women's March and Feminist Fest Indonesia activities involved various group of people in Indonesia.

Beside those two movements, the government of Indonesia has done collaborative action with United Nations Women (UN Women) to counter the gender equality and empower women issues. The activity focuses on strengthening law implementation and piloting for good practices (UN WOMEN, 2019). From three 
advocacy group, the feminist activists in Indonesia still focus traditional way of gender issues (UN WOMEN, 2019).

Eventhough the body shaming through social is new phenomenon, there is data that shows a large number of the case of women's body shaming on social media that happened in Indonesia. Reportedly, there were 966 cases of body shaming, the number shall be properly addressed and immediately became a concern. Based on the results of interviews by the Head of the Public Information Bureau of the Police Headquarters Public Relations Division Brigadier General Dedi, he said that in 2018 there were 966 cases of body shaming on social media that had been completed in 374 cases. But it uses a more humane approach or mediation between the two parties before being below to a more serious level of law (CNN Indonesia, 2018).

\section{Discussion}

\section{a. Self Objectivication}

Case of body shaming in Indonesia appear whether from direct conversation or through social media such as Facebook, Instagram, twitter, etc. Based on what Fredrickson and Roberts said, women will value themselves more based on people's views. The picture made by Hill and Fischer based on Fredickson and Robert's theory objectification, this research puts concern on path A. In this case, how is the change in sexual objectification to the stage of self-objectification that is influenced by the sexual orientation. Sexual orientation becomes a tool for changes that occur from sexual objectification to self-objectification.

Sexual objectification occurs continuously because it has become human nature. In the world of feminism, sexual objectification occurs when someone judges women based on their bodies both in terms of form and others. Sexual objectification usually occurs because someone has their own judgment, for example, seeing someone else being a little fatter, then starting to say that the person is fat. Although not necessarily through different perspectives will be considered fat too.

Normally someone does sexual objectification because they have had their sexual orientation. Sexual orientation has different sources, some measure based on using the Brosca formula until there are only those that use the senses of sight or the eyes. Everyone usually has a sexual orientation that is different 
this is because it is made aware of each individual's different interests. For example there is someone who likes to be fat, some like to be thin. However in this study, the brosca formula is not valid, because cases that occur on social media cannot find out whether the person is really fat or thin, as social media cannot tell how many sizes of weight or height of someone other than that person who tells himself. So that most cases of self objectifictaion that occur can be categorized as judgments only from the sense of sight. After this sexual objectification, people will enter self-objectification. Self objectification is carried out because the mind of a person has been disturbed by the values that are embedded due to people's comments. Self objectification does not only come from yourself but it occurs due to external factors, namely comments from others.
There are some people who are normal in responding but sometimes some others look very serious in dealing with it. Like the case of the artists, some just let it go but some chose to take legal action such as reporting to the police. In case of Dian Nitami, she has been shamed by people of her face through social media Instagram. That people comment her to do operation because she is an actress that must have perfect face. We can see that the sexual objectification that happen in Dian Nitami's case is body shamed based on sexual orientation which is actress must have perfect body no matter what. This builds people opinion to do the body shame on Dian Nitami. Because of cannot accept being acted like that, Dian Nitami decide to report to Police.

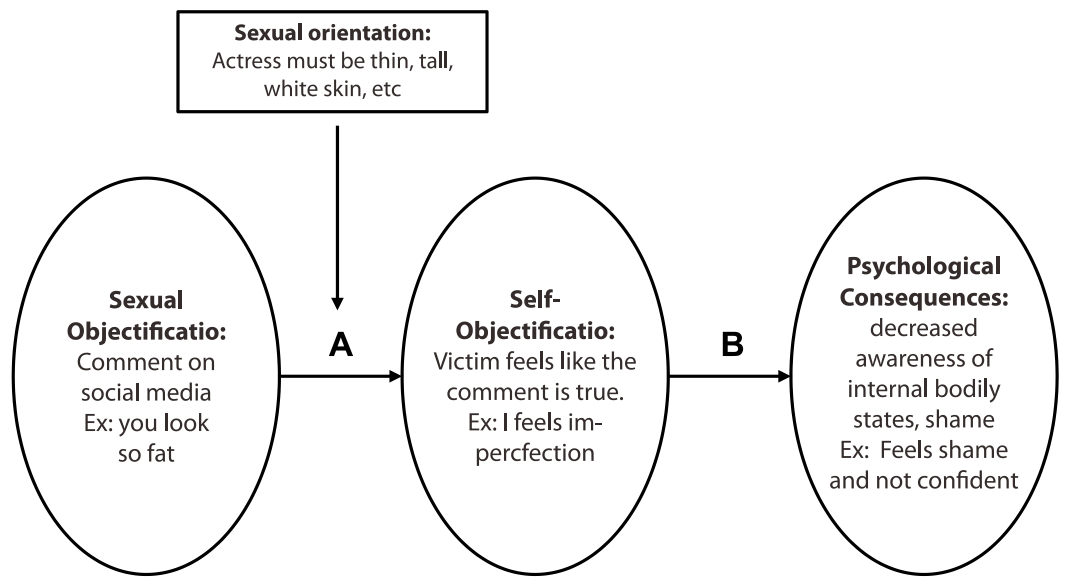


From case of Dian Nitami, we the viewer sexual orientation. This can see the sex orientation here is that as a public figure must be perfect in everything especially body. The figure above is clearly stated about how the process of body shaming that impact to the victim. Such as the actress must be thin, white, neat, tall, beautiful, high and small nose and many others as thing has been set up to the most of people mindset. They are trying to apply what do they like to people's look like by shamed the other people because beyond their expectation and their own standard.

\section{b. Emerging New Norms as Pra- ctical Order}

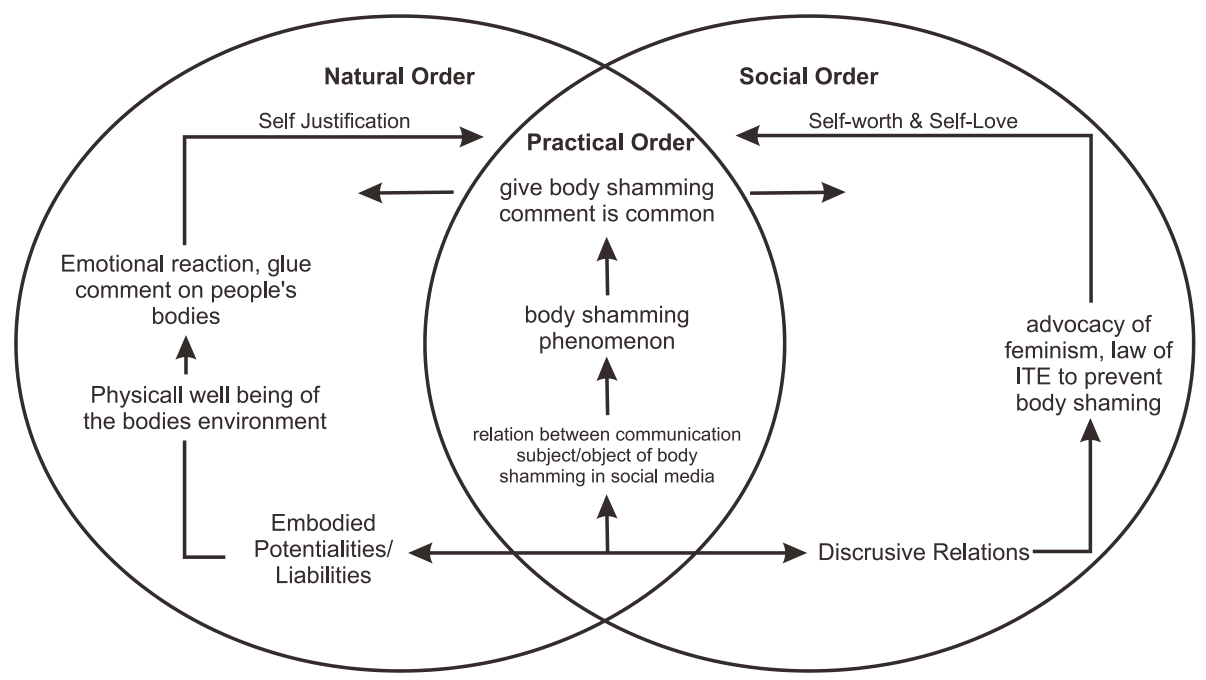

Source: (Clegg, 2006) based on Archer (2000)

In accordance with the findings, Archer's model about practical order can be the opposite of natural order and social order. The self-constituted in practical activity in relations with natural needs. Here the society concern of their physical well being of the body and the environment as the natural relation, and people have the emotional fuels to have internal conversation with themselves to questioning certain body image. This also part of their reaction towards the social construction of the ideal body image meets the reality. In the natural order the concern is about body image and emotional reaction is visceral. As the results, people have emotional reactions towards the body image and glue comment on people's bodies. Furthermore, self-justification becomes embodied knowledge in natural order. 
In the practical order, the parctical conciousness of the people is not the result of some intellectual capability of linguistic principles or syntax. In the case of Dian Nitami, the bullies are educated person, this shows that their consciousness does not have relations with the education degree. The centrality practice is tied to the fact that it is only through practice that human potential can be realized and personal identity formed. In this order, people communication through social media creates the pracical relations between the bullies and victims, people give harsh comment towards certain body shape because it does not meet their expectation. This proceeds to the phenomenon of body shaming in social media. Then, it is led to giving comment on people's body is common things, even though it might insult other's feeling.

For the third order, social order, discursive knowledge, the concern of the people -should be self-worth or self-love normative action. This should be the normative value and proportional culture that emerge because of the result of advocacy feminism and the ITE Law to prevent and stop the body shaming. However the dillemas for any individual are distinct and no guarantees that they are compatible. As the shole result, the contradiction between three orders rise and the new value has emerged, in this case is that giving body shaming comment to other individuals is common things.

\section{Conclusion}

So in the conclusion, why does the body shaming through social media happenings in Indonesia with fourth-wave feminism caused by habits formed in social life. This habit makes the mindset of most people doing body shaming that it is actually a normal thing to do. Even though the fact is that these things can have a major impact both directly and indirectly. Based on the model produced by Archer, there are two factors that influence the occurrence of body shaming through social media called natural order and social order. In this natural order talking about how self-justification as expressed in the theory of objectification that this can occur because of the sexual orientation in this case which says which is good and what is right. So when someone believes that it is the right thing, then the occurrence of body shaming on social media can be a justification for them. This is the basis for why this phenomenon still occurs in Indonesia. Because 
in Indonesia, commenting on the physical is an ordinary thing which is a supporting factor for them as a form of justification for the phenomenon of body shaming on social media.

\section{Bibliography}

Archer, M. S. (2000). Being Human The Problem of Agency. Cambridge: Cambridge University Press.

Arivia, G., \& Subono, N. I. (2017, September). A Hundred Years of Feminism in Indonesia: An Analysis of Actors, Debates and Strategies. Retrieved February 14, 2019, from Frederich Ebert Stiftung Website: http:// library.fes.de/pdf-files/bueros/ indonesien/13830.pdf

BBC. (2018, March 03). Aksi Women's March 2018 Indonesia: soroti pembunuhan perempuan, kekerasan pada pekerja, pernikahan anak. Retrieved from BBC INDONESI: https:// www.bbc.com/indonesia/ trensosial-43237965

Chamberlain, P. (2017). The Feminist Fourth Wave Affective Temporarility. London: Palgrave Macmillan.

Clegg, S. (2006). The problem of agency in feminism: a critical realist approach. Gender and
Education Vol. 18, No. 3, May 2006, 309-324.

CNN Indonesia. (2018, November 29). Polisi Sudah Terima Laporan Pengaduan Body Shaming Retrieved from CNN INDONESIA : https://www.cnn indonesia.com/nasional/2018 1128194119-12-350050polisisudah-terima-laporanpengaduan-body-shaming Cochrane, K. (2013, December 10). The fourth wave of feminism: meet the rebel women. Retrieved from The Guardian: https:// www. theguardian.com/ world/2013/dec/10/fourthwave-feminism-rebel-women

Detik.com. (2010, February 04). Diancam Putus, Pria Sebar Foto Bugil Pacar di Facebook. Retrieved from Detik.com Website: https://news.detik. com/berita/d-1293244/ diancam-putus-pria sebar-fotobugil-pacar-di-facebook

FEMFEST. (n.d.). Retrieved from Feminist Fest: http://femfest.id/ Fredickson, B. L., \& Roberts, T. A. (1997). Objectification Theory Towards Under standing Women's Lived Experiences and Mental Health Risks. Psychology of Women Quarterly, 21, 173-206. 
Gaffney, K. J. (2017). Negative affects that Social Media causes on Body Imaging. Undergraduate Honors College Theses, 13.

Gallivan, H. R. (2014, May 18). Teens, Social Media and Body Image. Retrieved from Minnesota Association for Children's Mental Health: https://www. macmh.org/wp-content/ uploads/2014/05/18_Gallivan_ Teens-social-media-bodyi mage - presentation- $\mathrm{H}$ Gallivan-Spring-2014.pdf

Gunawan, E. (2009, July 21). Menghina Felly Lewat Facebook, Farah Jadi Tersangka. Retrieved from News Okezone: https://news.okezone.com/ $\mathrm{read} / 2009 / 07 / 21 / 1 / 240639 /$ menghina-felly-lewat-facebook-farah-jadi-tersangka

Hill, M. S., \& Fischer, A. R. (2008). Examining Objectification Theory: Lesbian and Heterosexual Women's Experiences With Sexual and Self-Objectification. The Counseling Psychologist, 36, 745-776.

Kemp, S. (2018, January 30). Digital in 2018: World's Internet Users Pass the 4 Billion Mark. Retrieved from We Are Social: https://wearesocial.com/uk/ blog/2018/01/global-digitalreport-2018
Munro, E. (2013). Feminism: A Fourth Wave? SAGE Journals, 4(2), 22-25. doi:20419066.12021

Nazriani, D., \& Zahreni, S. (2016). Adolescent Cyberbullying in Indonesia; Differentiation between Bullies and Victim. ICOSOP. Atlantis Press.

Neuman, W. L. (2014). Social Re search Methods (7th ed.). Edin burg: PEARSON.

Rakhmat, M. Z., \& Tarahita, D. (2017, May 21). Social Media and Consumerism in Indonesia. Retrieved from Fair Obeserver: https://www.fairobserver.com/ region/asia_pacific/indonesiasocial-media-facebook-twitterinstagram-coldplay-concertsasian-news-44903/

Safaria, T., Tentama, F., \& Suyono, H. (2016). Cyberbully, Cyber victim, and Forgiveness among Indonesian High School Stu dents. The Turkish Online Journal of Educational Techno $\log y, 15(3)$.

Santoso, A. (2018, November 28). Polisi Tangani 966 Kasus Body Shaming Selama 2018. Retrieved from Detik.com: https://news. detik.com/berita/4321990/ polisi-tangani-966-kasus-bodyshaming-selama-2018 
$604 \quad \begin{aligned} & \text { Islamic World and Politics } \\ & \text { Vol. 3. No. 2, December } 2019\end{aligned}$

UN WOMEN. (2019). UN Women

Indonesia. Retrieved 01 20, 2019, from UN WOMEN:

http://asiapacific.unwomen. org/en/countries/indonesia 